\title{
MODEL SAVREMENOG SISTEMA FINANSIRANJA NA PRIMERU ISLAMSKOG BANKARSTVA
}

\author{
Snežana Lj. Krstić \\ Univerzitet odbrane u Beogradu, Vojna akademija \\ Milan J. Mihajlović \\ Visoka škola modernog biznisa, Beograd \\ Miloš N. Stanković \\ Visoka škola za menadžment i ekonomiju, Kragujevac
}

Slamsko bankarstvo je relativno novijeg datuma. Osnovna razlika u odnosu na klasično bankarstvo je u tome što se bazira na islamskom pravu, šerijatu. Šerijat zabranjuje uzimanje i davanje kamate. Takođe, šerijat ne dozvoljava ulaganje u poslove koji su u suprotnosti sa osnovnim postulatima verskog prava. Islamsko bankarstvo prioritet daje partnerskim odnosima između preduzetnika i finansijera i tzv „vlasničkim“ modelima finansiranja.

Ključne reči: islamsko bankarstvo, šerijat, beskamatno bankarstvo

Uvod

Islamsko bankarstvo spada u specifične oblike bankarstva koje posluje na principi-

Ima Kurana. Ono predstavlja deo šireg koncepta islamske ekonomije. Po Kuranu sva zemaljska blaga su dar Alaha, a čovek je poverenik Alaha koji poverenim resursima može da raspolaže za vreme ovozemaljskog života. Resurse koji su mu povereni čovek mora da koristi u cilju dobrobiti celokupnog društva, i ne sme in usmeravati u gomilanje blaga niti u špekulativne svrhe. Resursi, naravno, moraju da obezbede i materijalnu nagradu poverenicima Alaha, jer njihova racionalna upotreba stvara dodatnu vrednost.

U raznim filozofskim i religijskim učenjima kamata je smatrana moralno neprihvatljivim načinom sticanja bogatstva. Još su Platon i Aristotel kamatu tretirali kao 'neprirodan' način bogaćenja. Klasičari poput Smita i Rikarda svoje učenje bazirali su na teoriji radne vrednosti, a slično stanovište imali su i marksisti. Aktivnosti koje su bile primenjene u praksi, a dopuštene islamom, praktično su primenjene još u srednjem veku u Spaniji, Mediteranu, zatim na područjima čak do Indije, s obzirom da su muslimanski trgovci bili posrednici u trgovinskim transakcijama, a mnoge tehnike iz 'islamskih finansija' su kasnije primenjene od strane evropskih preduzetnika i finansijera.

Načela na kojima je zasnovan klasičan bankarski sistem izazvao je negodovanja u muslimanskom svetu, pa je došlo do stvaranja alternativnih sistema tj oblika bezkamatnog bankarstva. Sam termin ‘islamsko bankarstvo` je fenomen modernog doba, s obzirom da postoji nekoliko decenija. Prema raspoloživim podacima preko 300 banaka u 
svetu posluje u skladu sa islamskim načelima. Ključno načelo ovakvog oblika bankarstva je zabrana kamate ('riba') kao prinosa. „To ne znači da finansijer nema prava na prinos od uloženih sredstava, već da se visina prinosa mora dovesti u vezu sa ekonomskim rezultatom finansiranog projekta." ${ }^{1}$

Islamski sistem finansija odbacuje koncept po kome je zajmoprimac isključivo odgovoran za vraćanje duga, pri čemu je bitno naglasiti da u ovom sistemu zajmodavac preuzima na sebe rizik posla zajmoprimca a zajedno dele dobit i gubitak od tog posla. Dakle, zagovornici islamskog bankarstva kao veliku prednost vide podelu rizika između finansijera i preduzetnika što doprinosi većoj efikasnosti projekta i većoj motivaciji finansijera da se posveti uspehu projekta.

Izveštaji Ujedinjenih Nacija uveliko govore o neravnomernoj raspodeli svetskog bogatstva. Neka istraživanja su pokazala da veliki broj zemalja, pogotovo Trećeg sveta, mora da uzima zajmove da bi otplatili kamatu, pa je eliminisanje kamate po islamskim teoretičarima ključ ekonomskog razvoja.

\section{Istorijat razvoja islamskog bankarstva}

Moderne islamske banke se javljaju početkom 60-tih godina 20. veka, prvo u Egiptu. Mit Ghamr Saving Bank je bila prva islamska banka otvorena 1963. godine. Bila je organizovana na principu deljenja profita, u obliku štedionice. ${ }^{2}$ Međutim, 1967. godine napustila je model beskamatnog poslovanja i transformisala se u komercijalnu banku, pre svega zbog pritiska egipatske vlade koja tada nije bila naklonjena ovakvom obliku eksperimenta.

lako se u institucionalnom smislu islamsko bankarstvo razvilo u poslednjih 30 godina, sam pokret islamizacije bankarske delatnosti javio se početkom 20 . veka, a 60 -tih godina 20. veka ubrzano se razvijaju načela 'islamske ekonomije`. Njih su formirali teolozi bliski islamskom fundamentalizmu. ${ }^{3}$

U Maleziji je formirana finansijska institucija 1963. godine - Muslim Piligrims Saving Corporation, čiji je cilj bio da obezbedi sredstva za finansiranje obavljanja hodočašća u Meki. Institucija suštinski nije bila banka, ali je njen značaj bio u tome što je predstavljala osnov za formiranje prve islamske komercijalne banke u Maleziji - Islam Malaysia Berhad.

Značajnu podršku osnivanju islamskih banaka dale su Konferencija ministara islamskih zemalja u Karačiju 1970. godine, Islamski samit u Lahoreu 1974. godine, Prva islamska konferencija islamskih ekonomista u Meki 1976. godine, Međunarodna ekonomska konferencija u Londonu 1977. godine i slične konferencije.

Odlukom predsednika Egipta, 1971. godine, formirana je Naser social bank (Nasser Social Bank), prva banka iza koje se nalazila vlada jedne islamske zemlje. ${ }^{4}$

\footnotetext{
${ }^{1}$ Srđan Marinković, „Islamsko nasuprot konvencionalnom bankarstvu: uporedna analiza aranžmana finansiranja“, Bankarstvo 3, 2013, str. 106.

${ }^{2}$ Funkcionisala je kao štedionica i investiciona institucija, a ne kao komercijalna banka.

${ }^{3}$ Dragan Veselinov, Islamska ekonomija - teoekonomija u pokušaju, Almanah 65-66, Udruženje `Almanah`, Podgorica, 2015, str. 8.

${ }^{4}$ Iqbal Z., Mirakhor A., Uvod u islamske finansije - teorija i praksa, Mate, Zagreb, 2009, str. 23.
} 
Islamska razvojna banka osnovana je 1975. godine od strane Organizacije islamskih zemalja kao institucija za unapređenje ekonomskog razvoja i trgovine zemalja članica. Iste godine formirana je i prva privatna islamska banka - Dubai Islamic Bank. Dubai islamik bank (Dubai Islamic Bank) prva je privatna islamska banka koja je svoje poslovanje zasnovala na beskamatnoj osnovi, da bi po istom principu 1977. godine bile osnovane Feisal islamik bank (Faisal Islamic Bank) u Sudanu i Egiptu. ${ }^{5}$

Prvobitno je bilo predviđeno da sve banke islamskog tipa budu učlanjene u Međunarodnu asocijaciju islamskih banaka. Asocijacija je formirana avgusta 1977. godine pod pokroviteljstvom Organizacije islamske konferencije. Asocijacija je trebala da istraži pravila i proceduru organizacije islamskih banaka i njihovo osnivanje da bi se postigao jednoobrazni sistem islamskog bankarstva. ${ }^{6}$ Međutim, većinu poslova preuzele su druge međunarodne organizacije islamskog bankarstva, naročito Islamska banka za obnovu i razvoj.

Islamske banke se osnivaju i van teritorije islamskih zemalja. Islamic Banking System (Islamic Finance House) je zvanično prva islamska institucija osnovana u Evropi. Osnovana je u Luksemburgu 1978. godine. Ubrzo je formirana u Kopenhagenu i Islamic Bank International of Denmark. U Melburnu u Australiji je formirana Islamic Investment Company. U Švajcarskoj veoma su atraktivne Citibank i Union Bank of Switzerland, koje imaju sopstvene šaltere za beskamatno poslovanje. Zapadne konvencionalne banke su od samog početka bile vrlo agilne u radu islamskih finansija. ${ }^{7}$

Neke islamske banke su još na samom početku napustile koncept beskamatnog poslovanja, dok su neke koje su prethodno poslovale na konvencionalnoj osnovi, prešle na sistem poslovanja u skladu sa principima islamske ekonomije.

\section{Principi i instrumenti islamskog bankarstva}

Principi islamskog bankarstva predstavljaju skup šerijatskih principa (skup odluka i zakona), koji upravljaju svim sferama islamskog društva (ekonomskom, kulturnom, socijalnom i dr.). Šerijat (islamsko versko pravo) proizilazi iz Kurana, a osnovni princip bankarstva je da ono ne bazira na kamati ('riba'). U Surama (poglavljima muslimanske Svete knjige) propisana je zabrana davanja i uzimanja kamate. Ono što je izuzetno važno a odnosi se na zabranu kamate, je naglašena razlika između kamatnih transakcija i trgovine. Trgovina je dozvoljena, pa time i profit koji se dobija kroz nju. Teoretičari islamske ekonomije pokušavaju da objasne zabranu kamate ekonomskim razlozima: onemogućavanje međunarodne monetarne krize, sprečavanje pune zaposlenosti i sl. Oni čak tvrde da je jedan od najvećih uzroka svetske krize od 2008. godine, bila upravo kamata. Dakle, ključni princip ovog oblika bankarstva je zabrana kamate, kao prinosa čija je visina unapred utvrđena. To naravno ne znači da finansijer ne može da ostvari prinos po osnovu

\footnotetext{
${ }^{5}$ Fikret Hadžić, Islamsko bankarstvo i ekonomski razvoj, Ekonomski fakultet, Sarajevo, 2005, str. 161.

${ }^{6}$ The Journal og Islamic Banking and Finance, The International Association of Islamic Banks - main objectives, http://islamicbanking.asia/about-us/

${ }^{7}$ Uglavnom je to bilo uzimanje međubankarskih depozita od islamskih finansijskih institucija, a depoziti su bili prikupljeni od muslimanskog stanovništva u državama u kojima su ove banke formirane.
} 
uloženih sopstvenih sredstava, već da se visina prinosa mora dovesti u vezu sa ekonomskim rezultatom finansiranog projekta. ${ }^{8}$ Zagovornici islamskog bankarstva stoje na stanovištu da islamski model finansiranja, za razliku od sistema koji se zasniva na kamatnoj stopi, odbacuje mogućnost zavisnosti realnog sektora od interesa bankarskog kapitala.

Islamske banke ne traže zalog od klijenta, pa ta činjenica može dovesti do mahinacija i od strane klijenta i od strane same banke. Islamske banke su, da bi izbegle navedeni problem, razradile specijalnu proceduru koja je veoma bliska zapadnim bankama. Detaljan adut svih operacija klijenata je vid borbe sa mahinacijama. ${ }^{9}$ Tako se javlja situacija da perspektivni projekti koje zapadne banke odbacuju zbog nepostojanja zaloga, islamske banke mogu finansirati na osnovu učešća u profitu.

Evidentno je da je praksa formiranja islamskih specijalizovanih banaka pokazala da su one glavni instrument ostvarivanja ciljeva islamskog ekonomskog poretka. Taj poredak je predstavljao alternativu konvencionalnom ekonomskom poretku i konvencionalnom bankarstvu. Različitost koncepcija i pravaca u samom islamskom bankarstvu dovela je do potrebe prilagođavanja šerijatskih normi prema samoj formi bankarske operacije. Kao što je rečeno, islamski bankarski sistem zabranjuje uzimanje kamate, ali do sada nije formirano jedinstveno stanovište da li je zabrana usmerena isključivo ka zelenaštvu ili se odnosi na sve oblike bankarskog procenta. Činjenica je da se u Kuranu na mnogo mesta može naći zabrana 'ribe', ne može se naći ni jedan razlog njene zabrane niti precizna definicija samog termina.

U okviru islamskog bankarstva izdvojio se idealistički pravac koji pokušava da zadrži ideje nastale 50-tih i 60 -tih godina 20 . veka. Ovaj pravac propagira islamsko bankarstvo potpuno u skladu sa načelima šerijata. Liberalni pravac, kao potpuno suprotan prethodnom propagira da termin 'riba' ne obuhvata modernu bankarsku kamatu. Po njemu, pod uslovom da se u poslovanju prihvate etičke norme islama, tada i konvencionalne banke mogu pružati finansijske usluge muslimanima. Pragmatičari fleksibilnije pristupaju procesu interpretacije principa i tekstova islamskog prava.

Uglavnom pristalice idealističkog pravca koji dominira u islamskim zemljama prihvataju ekonomske principe poslovanja : vodeća uloga u akumulaciji kapitala treba da pripada državi, nikako se ne prihvataju bankarska ulaganja u privatne sektore privrede, zabranjuje se uzimanje kamate, traži se izdvajanje određenog procenta za siromašne i celokupno vaspitanje u duhu islama koji osuđuje laku zaradu.

$\mathrm{U}$ islamskom bankarstvu prepoznatljivo je korišćenje nekoliko dominantnih finansijskih aranžmana (instrumenata).

1) Mudareba - predstavlja zajedničko učešće islamske banke i njenog klijenta u nekom projektu. Cilj je ostvarenje saradnje između finansijera (banke, koja poseduje kapital) i preduzetnika. Profit se deli između ugovarača u proporciji koja je definisana shodno ugovorom. U situaciji kada je poslovni rezultat gubitak, banka gubi jedan deo uloženih

\footnotetext{
${ }^{8}$ Siddiqui Anjum, „Financial contracts, risk and performance of Islamic Banking“, Managerial Finance 10 , 2008, str. 680-694. (681)

${ }^{9}$ Jovan Dušanić, Bankarstvo, BPŠ, Beograd, 2013, str. 111.

${ }^{10}$ „Prema šerijatu, riba se tehnički odnosi na ‘premiju` koju dužnik mora da plati zajmodavcu zajedno sa iznosom glavnice kao uslovom za dobijanje zajma i produženjem perioda trajanja zajma. Četiri obeležja definišu zabranjenu kamatnu stopu: pozitivna je i fiksirana exante, vezana je za iznos zajma i period otplate, njeno plaćanje se garantuje nezavisno od ishoda ili namene zbog koje se glavnica pozajmljuje, državni organi odobravaju i sprovode njeno ubiranje." Iqbal Z., Mirakhor A., Uvod u islamske finansije - teorija i praksa, Mate, Zagreb, 2009, str. 52.
} 
sredstava, a preduzetnik materijalna ulaganja ukoliko in je imao, trud, vreme i nematerijalna ulaganja. Samo postojanje banke je ovim aranžmanom opravdano jer omogućuje direktnim investitorima da transformišu rizični u nerizični finansijski tok diversifikacijom ulaganja. Banka koja plasira sredstva ovim instrumentom ulazi u agentski odnos putem koga standardni odnos finansijera i preduzetnika prerasta u odnos investitora i agenta „jer aktera koji upravlja projektom a ne ulaže sopstvena sredstva ne možemo smatrati preduzetnikom u pravom smislu reči, već agentom". ${ }^{11}$

2) Mušareka - zajedničko ulaganje koje predstavlja oblik realizacije nekog projekta ili same operacije u kojoj obe strane odlučuju na osnovu sporazuma da svaka strana u posao ulaže kapital, a zajedno upravljaju projektom, sporazumno raspolažu radnom snagom i kapitalom i snose troškove realizacije projekta, dele profit i gubitke. Dok mudareba predstavlja oblik čistog finansiranja, mušareka predstavlja islamski oblik zajedničkog ulaganja. ${ }^{2}$ „Prinos od projekta se deli po ključu koji je unapred dogovoren između učesnika, a koji se može razlikovati od ključa koji se primenjuje u slučaju srazmernog snošenja gubitka. U prvom slučaju ostvareni profit će se deliti prema strukturi finansiranja koja se dalje koriguje izdvajanjem izvesnog dela naknade preduzetniku za upravljanje projektom. Kod alokacije gubitaka uvek se primenjuje ključ određen prema srazmeri u finansiranju projekta. Ova obeležja aranžman kategorišu u modele vlasničkog finansiranja." ${ }^{33}$

3) Murabeha - klijent daje banci preciznu specifikaciju robe i opreme koja mu je potrebna, a ugovorom se obavezuje da će nakon što to banka nabavi preuzeti $\mathrm{i}$ isplatiti u ratama. Stranke unapred usaglašavaju profit. ${ }^{14}$

4) Idžara - banka za klijenta kupuje potrebnu opremu, ali je ne prodaje već iznajmljuje. Ovo predstavlja oblik lizing posla. Razlika između ovog i drugih aranžmana je u tome što ovde naknada finansijeru može uključivati brojne elemente, i biti određena kompleksnijim formulama. ${ }^{15}$

5) Mukareda - „Tehnika koja dozvoljava emisiju specifičnih `islamskih obveznica`za finansiranje konkretnih projekata. Njen imaoc, slično kao vlasnik akcija bez prava glasa, ima pravo na deo profita, ali i obaveze za stvorene gubitke na projektu. “16

Mušareka kao instrument često ima prednost u realizaciji zajedničkih projekata između banaka i preduzetnika. 'Kratkoročne operacije' banaka su sumnjive i nisu poželjne. „Istraživanja koja su vršena u nekim islamskim zemljama (Saudijska Arabija i Pakistan) su pokazala da jedan (veoma važan) razlog negativnog odnosa preduzetnika prema operacijama koje pretpostavljaju učešće banke u prihodu od zajednički finansiranog projekta leži u njihovom izbegavanju da pred bankom do kraja otkrije svoje realno knjigovodstvo." 17

\footnotetext{
${ }^{11}$ Srđan Marinković, „Islamsko nasuprot konvencionalnom bankarstvu: uporedna analiza aranžmana finansiranja“, Bankarstvo 3/2013, str. 111, 112.

12 Jovan Dušanić, Bankarstvo, Beogradska poslovna škola, 2013, str. 113.

${ }^{13}$ Srđan Marinković, „Islamsko nasuprot konvencionalnom bankarstvu“, Bankarstvo 3/2013, str. 112.

14 Jovan Dušanić, Bankarstvo, BPŠ, str, 113.

${ }^{15}$ Srđan Marinković, „Islamsko nasuprot konvencionalnom bankarstvu: uporedna analiza aranžmana finansiranja“", Bankarstvo 3, 2013, Beograd, str. 110.

${ }^{16}$ Jovan Dušanić, Bankarstvo, BPŠ, 2013, str. 113.

17 Jovan Dušanić, Bankarstvo, str, 114.
} 


\section{Analiza finansijskih aranžmana - pravna osnova kreditnog ugovora}

Ugovor o kreditu je proizišao iz ugovora o zajmu, mada danas ima karakteristike koje ga čine odvojenim i različitim od ugovora o zajmu. ${ }^{18}$ Naime, kredit se uvek daje u novcu, a zajam može ali ne mora uvek biti dat u novcu. „Konačno, ugovor o kreditu je uvek teretni pravni posao, dok zajam može biti i dobročin." ${ }^{19}$ Našim propisima ${ }^{20}$ kao obavezni element ugovara o kreditu definisana je visina nominalne kamatne stope uz određenje da li je fiksna ili promenljiva, a ako je promenljiva onda definiše elemente na osnovu kojih se određuje. Zakon o obligacionim odnosima u članu 47. reguliše da je ugovor ništav 'kada je predmet obaveze nemoguć, nedopušten, neodređen ili neodrediv. Dalje, član 50. ovog Zakona kaže da je predmet obaveze odrediv ako ugovor sadrži podatke pomoću kojih se može odrediti. U savremenom zakonodavstvu kreditni ugovor mora da obezbedi ekonomsku i pravnu ravnopravnost ugovorenih strana, zatim efikasnu primenu ugovora putem jasnih ugovornih obaveza obe strane. U kreditnom ugovoru mora postojati finansijska obaveza koja mora biti određena unapred i na koju ne može uticati nijedna od ugovornih strana.

Islamsko bankarstvo kritikuje konvencionalni kreditni ugovor, kao finansijski aranžman kome se osporava ravnopravnost u položaju ugovornih strana, implicitno favorizuju vlasničke oblike ulaganja, kao aranžmane kod kojih je nagrada koja pripada svakom ekonomskom faktoru dovedena u vezu sa njegovim doprinosom ostvarenom rezultatu. ${ }^{21}$

„Pregledom osnovnih stavova savremene teorije poslovnih finansija uočavamo da kreditni ugovor ima značajne prednosti u odnosu na vlasnička ulaganja spoljnih investitora, jer spoljni investitor lakše uočava povredu interesa i lakše reaguje u cilju prevencije i to naročito u slučaju kada ne raspolaže koncentrisanom pozicijom. Međutim, islamski finansijski aranžmani zasnovani na vlasničkom obliku ulaganja uglavnom podrazumevaju visok stepen koncentracije vlasničke pozicije, pa brojne primedbe u vezi neefikasnosti zaštite interesa manjinskih akcionara ovde nisu od posebnog značaja. "22

\section{Regulatorni okvir islamskog finansijskog sistema}

Muslimansko pravo (fikh) je deo šerijata, kojim se razmatraju i uređuju pitanja ubiranja poreza od muslimana i nemuslimana, norme kojima se regulišu trgovinske i finansijske transakcije, pravila proizvodnje i potrošnje i sl. U ranijim vremenima su se kupoprodajni ugovori zaključivali kod verskih sudija - kadija, pa je uticaj religije na društveni i privatni život ljudi bio znatno dominantniji nego npr. u hrišćanskim zemljama ili zemljama Dalekog istoka , u kojima je svetovna vlast uređivala krivično i građansko pravo. Hrišćani

\footnotetext{
${ }^{18} \mathrm{U}$ komparativnom pravu

${ }^{19}$ Milorad Bejatović, Bankarsko pravo i hartije od vrednosti, Privredna akademija, Novi Sad, 2008, str, 86.

${ }^{20}$ "Zakon o zaštiti korisnika finansijskih usluga“, Službeni glasnik RS br. 36/11, član 9 , tačka 6 .

${ }^{21}$ Srđan Marinković, „Islamsko nasuprot konvencionalnom bankarstvu“, Bankarstvo 3/2013, str. 116.

${ }^{22}$ Ibid., str. 119-120.
} 
nisu nikada davali prednost verozakonskim u odnosu na svetovne pravne norme, dok kod muslimana od nastanka religije do kraja 19. veka, muslimanski svet nije znao za druge sisteme zakona osim šerijatskog.

Po Feldmanu ${ }^{23}$ (Noah Feldman) „sistem islamskog zakonodavstva, kakav je nastao u prvo vreme islama, dozvoljavao je veliku meru slobodnog prostora, zbog čega današnji zagovarači šerijata kao izvora zakona u suštini ne sugerišu usvajanje sveobuhvatnog pravnog kodeksa izvedenog iz šerijata ili određenog šerijatom." ${ }^{24}$

Šerijat predstavlja uspostavljanje pravnog sistema, gde Božiji zakon treba da uspostavi norme i načela, koja daju legitimitet zakonima koje usvaja i donosi izabrani zakonodavni organ. Feldman navodi primere Partije pravde i napretka u Maroku i Muslimanske braće u Egiptu, čije platforme sadrže stav da izabrano zakonodavno telo treba da predlaže i usvaja zakone koji su u skladu s duhom islamskog zakona. U pitanjima gde islamski zakon ne daje smernice, demokratski izabrano zakonodavstvo treba da usvoji zakone nadahnute islamskim vrednostima. ${ }^{25}$

Postoje velike razlike u mišljenjima i stavovima po pitanjima osnivanja, organizacionih oblika, načina izveštavanja, pravilima poslovanja islamskih banaka, pa se regulatorni okvir razlikuje po državama. ${ }^{26}$ Formirano je više međunarodnih regulatornih organizacija pri pokušaju uvođenja standardizacije u navedenoj oblasti. Jedna od regulatornih institucija je i Računovodstvena i revizorska organizacija za islamske finansijske ustanove $(\text { AAOIFI) })^{27}$ i Islamski odbor za finansijske usluge (ISFB).

AAOIFI, pri utvrđivanju računovodstvenih standarda, polazi od shvatanja da nisu svi konvencionalni računovodstveni standardi u suprotnosti sa zahtevima islamske finansijske doktrine. Ova organizacija pristupa izradi novog standarda samo u slučaju da postojeći konvencionalni standard nije u skladu sa načelima šerijata.

ISFB, za razliku od AAOIFI-a koji se bavi računovodstvenim stanovištem islamskih finansijskih usluga, razvija nove standarde islamskog bankarskog sektora, osiguranja i tržišta kapitala radi uspostavljanja stabilnosti u oblasti islamskih finansija.

Šerijatski odbori imaju glavnu ulogu u nadzoru poslovanja islamskih banaka i osiguravajućih društava. Oni kontrolišu usklađenost finansijske aktivnosti sa šerijatom, a članovi odbora su priznati islamski teolozi i poznavaoci islamskog prava i finansija. Rad šerijatskog odbora predstavlja veliko finansijsko opterećenje za banku, ${ }^{28}$ pa se često $u$ islamskim poslovnim krugovima vodi rasprava o delovanju šerijatskih odbora pa i o njihovoj opravdanosti. Članovi šerijatskog odbora imenuju se od strane akcionara banke, ${ }^{29}$ kojima i podnose izveštaj. Akcionari odlučuju o visini finansijske naknade članova šerijatskog odbora, pa se

\footnotetext{
${ }^{23}$ Profesor Univerziteta Harvard.

${ }^{24}$ Feldman N., 2008, Why Shariah (Zašto muslimani žele šerijat), str. 4, s engleskog preveo i priredio Aid Smajić, http://www.google.rs/url?url=http://www.bosanskialim.com/rubrike, tekstovi

${ }^{25}$ Feldman N., Zašto muslimani žele šerijat, str. 4.

${ }^{26}$ Indonezija, Iran, Liban, Pakistan, Sudan Turska, Malezija, Jemen i Ujedinjeni Arapski Emirati su doneli zakone o islamskom bankarstvu.

${ }^{27}$ Je nezavisna, neprofitna organizacija osnovana u Alžiru 1990. godine, zvanično registrovana sa sedištem u Bahreinu 1991. godine

${ }^{28}$ Čas rada jednog člana šerijatskog odbora kreće se između 1000 i 1500 američkih dolara.

${ }^{29}$ Koje predstavlja bord direktora.
} 
postavlja pitanje da li takva pozicija članova šerijatskog odbora može dovesti do sukoba interesa. Članstvo u šerijatskom odboru podrazumeva znanje i praktično iskustvo iz oblasti ekonomije i prava, pa se često postavlja pitanje kompetentnosti članova odbora.

Pitanje zabrane uzimanja kamate ${ }^{30}$ ostaje i dalje glavni problem islamskih finansija na raznim skupovima i forumima, s obzirom da danas nema nijedne islamske zemlje koja ne obavlja poslove plasmana sa nemuslimanskim državama.

Zabrana kamate je najvećim delom zaustavljala razvoj kreditnih odnosa u muslimanskim državama. Ona koči aktivnost islamskih banaka, pa one ne mogu biti subjekti na međunarodnom tržištu kredita. Islamske banke počinju, da bi izbegle sukobe sa šerijatom $^{31}$, da modifikuju bankarske operacije, koje po ciljevima ne odstupaju od tradicionalnih bankarskih operacija, što za posledicu ima činjenicu da islamski naftni dolari ulaze u zapadnoevropske i američke banke.

\section{Islamske banke u SAD i EU}

Za razliku od Evrope, na području SAD-a još uvek nije osnovana banka koja u potpunosti pruža usluge islamskog bankarstva. Na teritoriji SAD-a je osnovano nekoliko investicionih fondova koji svojim ulagačima daju mogućnost da ostvaruju profit na halal ${ }^{32}$ način. Trenutno na tržištu SAD-a funkcioniše 15 investicionih fondova sa ukupnom aktivom 3,6 milijardi američkih dolara. Fondovi sredstva ulažu u odabrane sektore, pri čemu nije dozvoljeno ulaganje u akcije kompanija duvanske industrije, proizvodnje i distribucije alkoholnih pića, proizvoda svinjskog porekla, finansijske derivate i dužničke instrumente. Dau Džons islamski indeks (Dow Jones islamic index) omogućava da se vrši selekcija i eliminacija kompanija koje proizvode i stiču dobit na način suprotan šerijatskim pravilima. Prvo se eliminišu kompanije duvanske industrije, industrije alkoholnih pića i proizvoda svinjskog porekla, zatim se vrši eliminacija kompanija koje imaju veliki stepen zaduženosti i kompanija čiji je osnovni izvor prihoda kamata.

EU je vodeći spoljnotrgovinski partner zemalja Golfskog zaliva, pri čemu je 13,4\% ukupne trgovine tih zemalja povezano sa EU. Broj muslimanskog življa u Evropi neprestano raste i sada iznosi više od 45 miliona ljudi. Migracije stanovništva imaju najvažniju ulogu u rastu broja stanovnika islamske konfesionalnosti u Zapadnoj Evropi. Do 2030. godine, predviđa se dupliranje broja muslimana u nekim delovima Evrope. Islamski ekonomisti naglašavaju da regulatorni okvir EU ne predviđa model islamskog bankarstva kao specifikum, već su „islamske banke u obavezi da svoje poslovanje usklade sa važećim zakonskim propisima, u okviru kojih moraju tražiti načine ostvarivanja svojih poslovnih i razvojnih ciljeva. ${ }^{33}$ Islamska bankarska literatura navodi da bankarska praksa EU može da koristi islamsko bankarstvo, ali 'čiste` islamske banke u konvencionalnom siste-

\footnotetext{
${ }^{30}$ Problem zabrane kamate o kome se govori u Kuranu dovodi se u sukob sa praksom gde je ipak dozvoljeno uzimati kamatu u prikrivenom obliku, jer dok islamski teoretičari i ideolozi polemišu po ovom pitanju, činjenica je da kraljevi nafte u Kuvajtu, Saudi Arabiji i drugim islamskim državama drže svoj kapital u velikim svetskim (američkim i evropskim) bankama, govoreći da je sam kapital dozvoljeno eksploatisati.

${ }^{31}$ Ranije je pomenuto da šerijat dozvoljava trgovinu i davanje sredstava bez uzimanja kamate.

${ }^{32}$ Islam, kao osnovni cilj protežira uspostavljanje skupa principa i mera, na čijem osnovu se bazira kriterijum šta je dopušteno (halal), a šta je zabranjeno (haram).

${ }^{33}$ Fikret Hadžić (2005), Islamsko bankarstvo i ekonomski razvoj, Ekonomski fakultet, Sarajevo, str. 306.
} 
mu moraju da prilagode upravljanje aktivom i obavezama, kao i ograničavanje upravljanja rizicima i plasmanima, pa se dovodi u pitanje i samo postojanje islamskih banaka u EU. Neophodno je uskladiti zakonodavni okvir EU sa poslovnom praksom koja se bazira na šerijatu, što je najveći problem. Islamski bankari navode da bi islamske banke mogle da se susreću sa velikim problemima, pre svega to su sudski sporovi pred evropskim sudovima zbog nepoznavanja prirode odnosa ugovornih strana kada su u pitanju određeni finansijski instrumenti. Veliki problem predstavlja i poreski tretman poslova koji se zasnivaju na podeli gubitka i dobiti zbog tzv. 'dvostrukog oporezivanja'.

\section{Zaključak}

Uprkos činjenici da se termin islamsko bankarstvo i islamske banke danas uobičajeno koriste, tekući trend se kreće u smeru češćeg preferiranja naziva islamske finansije i investicije i islamske finansijske institucije.

Težnja da se islamske finansijske institucije razlikuju od zapadnih komercijalnih banaka ${ }^{34}$ proizilazi iz činjenice da je baza za osnivanje komercijalnih banaka čisto materijalistička filozofija, ${ }^{35}$ dok islamske banke imaju za cilj ispunjavanje socijalnih, razvojnih i drugih opštedruštvenih zadataka. Osnovna razlika islamskih i konvencionalnih banaka je u tome što u islamskom obliku bankarstva ne postoji kamata kao 'cena novca'.

Danas su zapadne banke, nastojeći da privuku islamski kapital, bitni učesnici u islamskoj trgovini, a sve sa namerom da iskoriste novootkrivena tržišta, ${ }^{36}$ pa je uočljivo da je Zapad povećao interesovanje za islamske finansije.

Međutim, uprkos datim primerima pokušaji da današnje komercijalne banke usklade svoje poslovanje sa islamskim zahtevima često nemaju potpunog uspeha. Islamski teoretičari smatraju da nije dovoljno samo 'ukinuti kamatu', već je potrebno da se u poslovanje konvencionalnih banaka ugradi islamska poslovna svest.

Prepreka širenju ideje islamskog bankarstva u zapadnom svetu predstavlja i poreska regulativa u nemuslimanskim zemljama. Prisutna je i zamerka da odredbe Banke za međunarodna poravnanja neke islamske banke ne poštuju do kraja.

Principi konvencionalnog bankarstva koji se uglavnom osporavaju u islamskom poslovanju su: pravo na povraćaj uložene sume novca nezavisno od rezultata projekta i pravo davaoca zajma na nadoknadu koja nije utvrđena u skladu sa rezultatima projekta koji je finansiran.

Islamsko bankarstvo je, bez obzira na dominaciju u zemljama koje su svoj finansijski sistem potpuno islamizovale (Pakistan, Iran, Sudan), ipak ostalo u skromnim srazmerama u odnosu na konvencionalno bankarstvo. Takođe, u ostalim zemljama u kojima je islam zvanično prihvaćena religija a nisu svoje finansije potpuno islamizovale, islamske institucije posluju u konkurenciji sa konvencionalnim bankama.

\footnotetext{
${ }^{34}$ Koje se identifikuju konvencionalnim odnosom kreditor - debitor.

${ }^{35}$ Koja ima vrlo malo veze sa međuljudskim odnosima.

${ }^{36}$ Tako je Citibank iz SAD-a bila prva konvencionalna banka čije je učešće sa kapitalom od 20 miliona dolara bilo usmereno za osnivanje islamske banke u Bahreinu.
} 


\section{Literatura}

[1] Bejatović, M., Bankarsko pravo i hartije od vrednosti, Privredna akademija, Novi Sad, 2008.

[2] Veselinov, D., Islamska ekonomija - teoekonomija u pokušaju, Almanah 65-66, Udruženje ‘Almanah', Podgorica, 2015.

[3] Dušanić, J., Bankarstvo, BPŠ, Beograd, 2013.

[4] Zakon o zaštiti korisnika finansijskih usluga, Službeni glasnik RS br. 36/11

[5] lqbal, Z., Mirakhor, A., Uvod u islamske finansije - teorija i praksa, Mate, Zagreb, 2009.

[6] Krstić S. (2016) Značaj institucije Centralne banke za nacionalnu ekonomiju, ODITOR, vol. 2, br. 2, str. 18-26.

[7] Marinković, S., „Islamsko nasuprot konvencionalnom bankarstvu: uporedna analiza aranžmana finansiranja“, Bankarstvo 3/2013.

[8] Milojević I., Mihajlović M., Vladisavljević V. (2018) Methodological Aspect of Controlling Corporate Income Tax, Vojno delo, Vol. 70, No 1, str. 103-111

[9] Mihajlović M., Imamović N., Dragović N. (2018) Uloga i značaj antimonopolske politike u savremenim uslovima poslovanja (revidiran rad), ODITOR, vol. 4, br. 2, str. 104-114.

[10] Siddiqui, A., „Financial contracts, risk and performance of Islamic Banking“, Managerial Finance 10, 2008.

[11] Hadžić, F., Islamsko bankarstvo i ekonomski razvoj, Ekonomski fakultet, Sarajevo, 2005.

[12] The Journal of Islamic Banking and Finance, The International Association of Islamic Banks - main objectives, http://islamicbanking.asia/ about-us/

[13] Feldman, N., 2008, Why Shariah (zašto muslimani žele šerijat), str. 4, s engleskog preveo i priredio Aid Smajić, http:www.google.rs/url=http://www.bosanskialim.com/rubrike.tekstovi 